\title{
GRANITOIDS MARKING THE END OF THE BRASILIANO (PAN - AFRICAN) OROGENY WITHIN THE CENTRAL TECTONIC DOMAIN OF THE BORBOREMA PROVINCE
}

\section{IGNEZ DE PINHO GUIMARÃES ${ }^{1}$, CÍCERA NEYSI DE ALMEIDA ${ }^{1}$, ADEJARDO FRANCISCO DA SILVA FILHO ${ }^{1}$ AND JOÃO MARIA MARTINS DE ARAÚJO ${ }^{1}$}

\begin{abstract}
The studied syenogranite and granodiorite intrusions have a similar U-Pb zircon age ( $c a 570 \mathrm{Ma}$ ). They are intruded in the Central Tectonic Domain of the Borborema Province, forming an S-type belt in relation to the Patos and Pernambuco Lineaments. The studied granitoids are clinopyroxene biotite leuco-syenogranites of the Solidão Pluton; amphibole biotite sienogranites from the Queimadas Pluton; biotite granodiorite and amphibole biotite granodiorite, which occur as dikes cutting the Itapetim Complex and leuco-syenogranites from the Serra Branca Pluton. They show geochemical data transitional between shoshonitic and alkaline series. Deep troughs at Nb, Sr, P and Ti and high LILE/HFSE ratios characterize the spiderdiagram patterns. The ÎNd $(0.6 \mathrm{Ga})$ values are extremely negative (- 11 to -16 ; except for the Itapetim dykes $\sim-3$ ) and $\mathrm{Nd}$ model ages $\left(\mathrm{T}_{\mathrm{DM}}\right)$ range from $2.0 \mathrm{Ga}$ to $2.5 \mathrm{Ga}$ (the Itapetim dykes $\sim 1.4 \mathrm{Ga}$ ). Biotites of the studied granitoids are $\mathrm{Fe}$-rich with $\mathrm{Fe} /(\mathrm{Fe}+\mathrm{Mg})$ ratios in the 0.62 to 0.84 range. Biotites from older granitoids $(640 \mathrm{Ma}-580 \mathrm{Ma})$ of the Pajeú - Paraíba Terrane, have $\mathrm{Fe} /(\mathrm{Fe}+\mathrm{Mg})$ ratios $<0.60$. The isotopic and geochemical data suggest that the studied granitoids correspond to a trans-alkaline, ferro-potassic plutonism, originated by partial melting of Paleoproterozoic and Mesoproterozoic crusts, emplaced during the final stage of the Brasiliano Orogeny in the Central Tectonic Domain of the Borborema Province.
\end{abstract}

Keywords: granites, Brasiliano, post-collision

INTRODUCTION The principal magmatic feature of the Brasiliano in the Borborema Province, Northeastern, Brazil, is a large number of granitic intrusions coeval with the development of continental-scale transcurrent shear zones and high-grade metamorphism (Vauchez et al. 1995). Geochronological data indicated a long period of granitic magmatism within the Borborema Province, during the Brasiliano Orogeny: 640Ma - 520Ma (Guimarães et al. 1998, Da Silva Filho et al. 1997).

In the past few years, we have been investigating granitoids from the Pajeú Paraíba Belt, Central Tectonic Domain (CTD) of the Borborema Province and here, we summarize the field features geochemical and isotopic data of granitoids that form an S-type belt between the Patos Lineament (North) and Pernambuco Lineament (South).

REGIONAL SETTING The Borborema Province represents one of the Neoproterozoic collisional belts of Gondwana that may have evolved in two-stages during the Pan-African / Brasiliano Orogeny: 750-660Ma and 650-580Ma (Liégeois et al. 1994). However, the precise timing of the Brasiliano Orogeny is poorly constrained.

The evolution of the Borborema Province has been described in the last few years, as a collage of terranes during different orogenic events (Santos 1995, Medeiros et al. 1997). According to Santos et al. (1997), the collage of terranes in the CTD occurred in two orogenic events: Cariris Velhos- Kibaran $(1.1-0,95 \mathrm{Ga})$ and Brasiliano - PanAfrican (0.75-0,57Ga). Within the so-called Pajeú-Paraíba Belt (Brito Neves 1983), which is part of the CTD, Santos (1995) and Medeiros et al. (1997) recognized three distinct terranes: The Alto Moxotó Terrane (AMT), Alto Pajeú Terrane (APT) and Rio Capibaribe Terrane (RCT). The studied granitoids are located in the APT and AMT.

\section{PETROGRAPHIC AND FIELD CONSIDERATIONS The} Queimadas Pluton is an elongated intrusion cropping out in an area of about $50 \mathrm{Km}^{2}$. It has been interpreted as a megadike deformed under high temperature conditions (Almeida 1999). Later transcurrent shear zones (N60E) cut the intrusion giving a megaboudin shape to the body. Petrographically, it is very monotonous, consisting of coarsegrained leucocratic monzogranites to granodiorites, which contains rare small mafic enclaves. The main mafic phase is biotite (2\%). Small modal volume of amphibole $(<1 \%)$ was recorded. The accessory phases are sphene, allanite, apatite, zircon and opaques.

The Serra Branca Pluton is an approximately $300 \mathrm{Km}^{2} \mathrm{E}-\mathrm{W}$ elongated pluton, which intrudes mainly gneisses and migmatites (including mylonites) of possible Archean age. It is bounded in the south by the E-W Coxixola transcurrent dextral Shear Zone. It is composed of fine-grained gray biotite leuco-syeno to monzogranites showing banded flow structures and near solid state foliation, suggesting that the emplacement of this pluton involved distinct batches of magmas during shearing. Biotite is the only major mafic phase and occurs as isolate flakes or, as oriented clots, following the magmatic flux direction. It constitutes less than $10 \%$ of the mode. The accessory minerals are allanite sometimes showing epidote rims, zircon and apatite.

The Solidão Pluton is a $250 \mathrm{~km}^{2}$ pluton, intruded into sillimanite bearing biotite-gneiss, locally migmatized, and is associated to the Solidão transcurrent dextral shear zone (Araújo et al. 1996). It is constituted by medium to coarse-grained monzogranites to granodiorites. The main mafic phases $(\sim 10 \%$ of the mode) are clinopyroxene (salite) and amphibole. Biotite constitutes less than $2 \%$ of the mode. The accessory phases are allanite, sphene, zircon and apatite.

The Itapetim late dykes are medium-grained granodiorite, which crosscut the porphyritic monzogranite and the country rocks of the Itapetim Complex (Guimarães \& Silva Filho 2000), corresponding to the Itapetim-type granite described by Almeida et al (1967). Widths range from centimeters to dozens of meters. Most of the dikes occupy brittle fractures. Banded flow magmatic structures are common. The granodiorites can be divided into two sub-facies: biotite granodiorite and amphibole-biotite granodiorite. The most abundant mafic mineral is biotite $(<15 \%)$. Sphene, epidote, apatite and zircon are the accessory phases.

GEOCHRONOLOGY AND Sm - Nd DATA U/Pb zircon analysis for the Solidão, Queimadas and Serra Branca Plutons were performed in the Isotope Geochemistry Laboratories-Kansas University - USA, following the methodology described by Van Schmus et al. (1995).

Four zircon fractions from the Solidão Pluton give a minimum age of $572 \pm 21 \mathrm{Ma}$.(Fig. 2A). There is a large inherited component present in the rock that has a minimum age of $2.1 \pm 62 \mathrm{Ga}$. These results are similar to those recorded by Kozuch et al. (1997). The minimum age of the inherited component is similar to the Sm-Nd TDM ages recorded in the Solidão granitoids $(2.07$ to $2.14 \mathrm{Ga})$

Four zircon fractions from the Queimadas Pluton give an upper intercept age of $570 \pm$. $24 \mathrm{Ma}$ (Fig. 2B) when the lower intercept is forced to zero. The Queimadas granitoids have Sm-Nd TDM ages similar to those recorded in the Solidão granitoids (2.04 - 2.17Ga.)

The Serra Branca granitoids contain zircons which give an age o $575 \pm 16 \mathrm{Ma}$. These granitoids show Sm-Nd TDM ages higher (2.3 to $2.5 \mathrm{Ga}$ ) than those recorded in the Solidão and Queimadas Plutons. It suggests that an Archean component may have been involved in the source of the Serra Branca granitoids.

Geochronological data are not available for the Itapetim dikes. However, the field relationships, mineral chemistry and whole rock geochemistry, suggest that they are co-magmatic with the ca 570Ma 


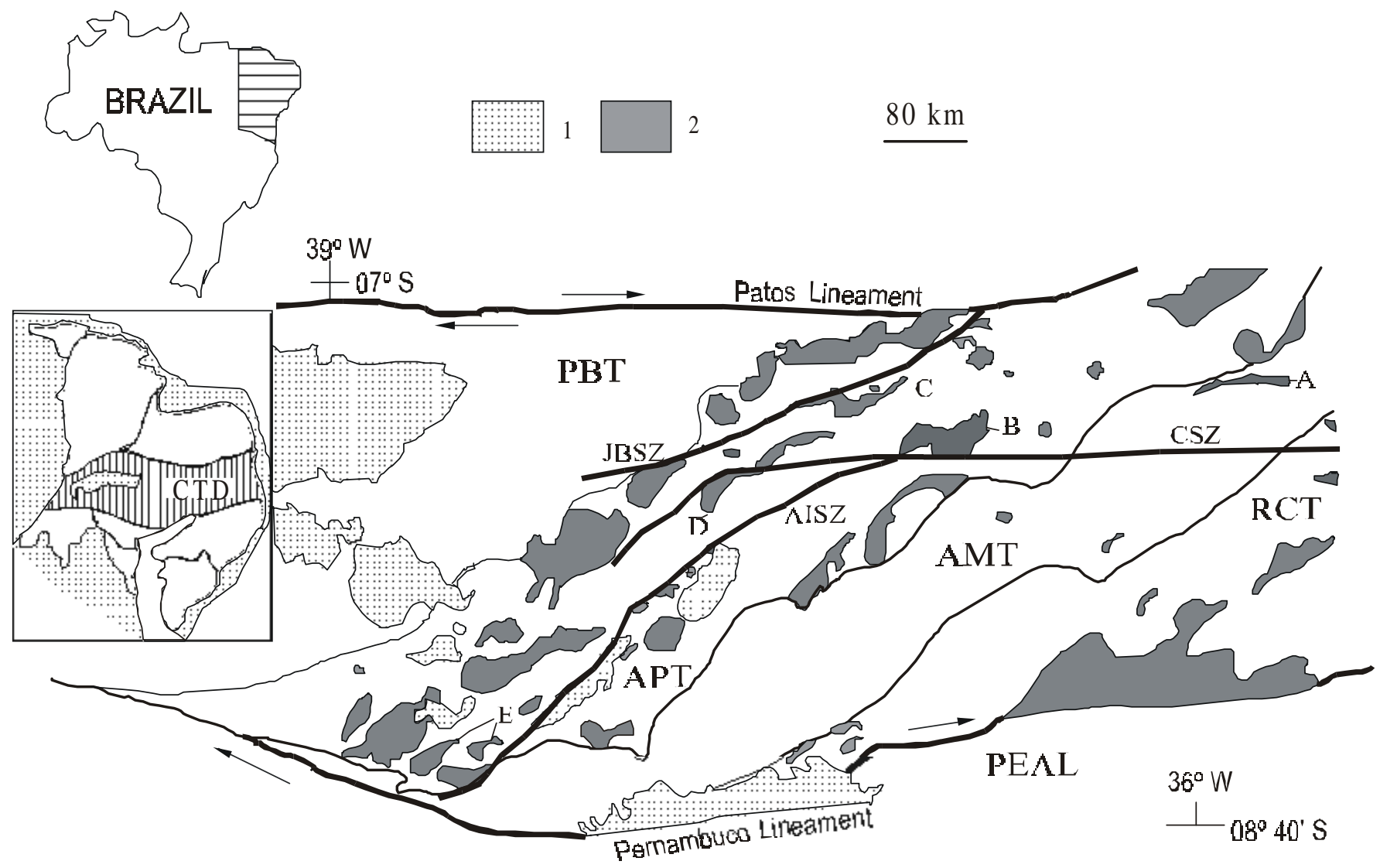

Figure 1-The location map of the studied granitoids. A = Queimadas Pluton; $B=$ Serra Branca Pluton; C Itapetim Dykes (cut the Itapetim Complex); D = Solidão Pluton and E = Serra Grande and Serra do Arapuá Plutons. Modified from Medeiros et al. (1996) and Santos et al. $(1996)$. CSZ = Coxixola Shear Zone; AISZ = Afogados da Ingazeira Shear Zone; JBSZ = Jurú - Belem Shear Zone. PBT = Piancó Alto Brígida Terrane; AMT = Alto Moxotó Terrane; APT = Alto Pajeú Terrane; $R C T=$ Rio Capibaribe Terrane. $C T D=$ Central Tectonic Domain $; 1=$ Phenerozoic Covers and $2=$ Brasiliano/Pan-African granitoids

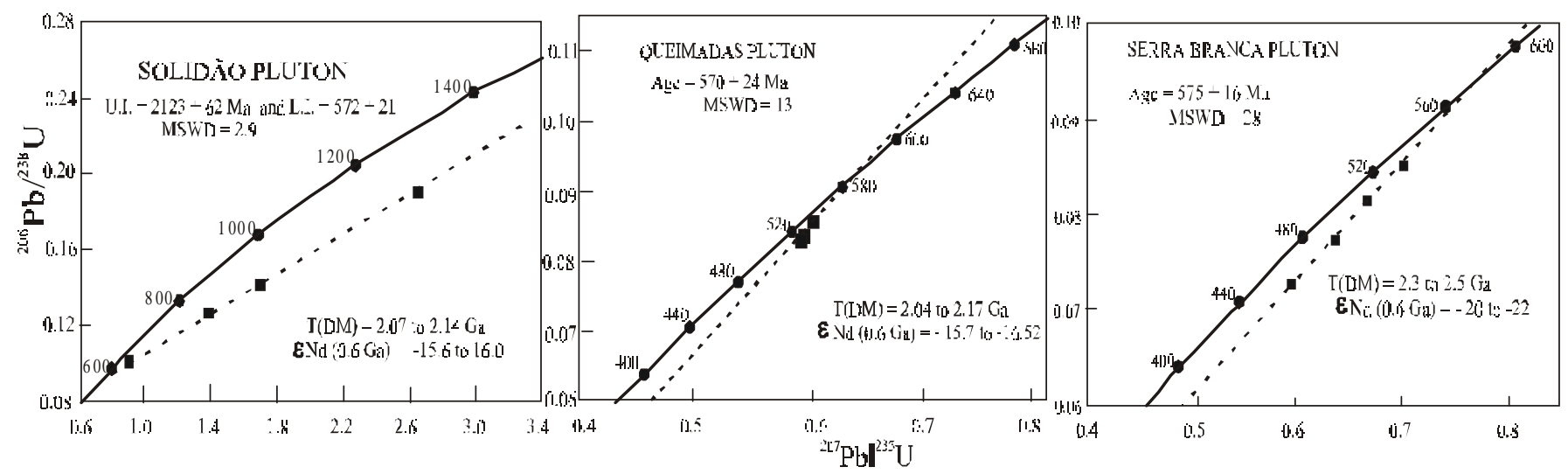

Figure 2-U-Pb zircon age determination and Sm-Nd isotopic data for the ca 570Ma granitoids from the Central Tectonic Domain of the Borborema Province.

granitoids from the Pajeú Paraíba Belt. Sm-Nd TDM ages of $\sim 1.4 \mathrm{Ga}$ for these granitoids, suggest a Mesoproterozoic source (Guimarães \& Silva Filho 2000).

MINERAL CHEMISTRY Biotite and amphibole compositions were determined on the JEOL- Superprobe at the Institute of Geosciences University of São Paulo.

Biotite The biotites from the studied granitoids are iron-rich with $\mathrm{FeO}$ contents in the $25 \%-28 \%$ range and $\mathrm{Fe} /(\mathrm{Fe}+\mathrm{Mg})$ ratios ranging from 0.62 to 0.85 (Fig. 3A). The Mg-poorer biotites are those from the amphibole and clinopyroxene-free granitoids (Queimadas and Serra Branca Plutons).

According to Abdel-Rahman (1994), $\mathrm{FeO} / \mathrm{MgO}$ ratios in biotites define three compositionally distinct fields: 1) biotites from alkaline anorogenic suites are iron-rich siliceous annites, with mean $\mathrm{FeO} / \mathrm{MgO}$
$=7.04 ; 2)$ biotites from the peraluminous granitoids, including the $S$ type, are siderophyllite with mean $\mathrm{FeO} / \mathrm{MgO}$ ratio $=3.48$; and 3 ) biotites from the calc-alkaline granitoids are moderately $\mathrm{Mg}$-enriched, with $\mathrm{FeO} / \mathrm{MgO}$ ratios of 1.76 on average. Biotites from the freeamphibole and clinopyroxene studied granitoids show $\mathrm{FeO} / \mathrm{MgO}$ ratios ranging from 6.4 to 8.4. Biotites from the amphibole clinopyroxene bearing granitoids show $\mathrm{FeO} / \mathrm{MgO}$ ratios ranging from 2.5 to 3.7 .

High temperature conditions favor accommodation of Ti instead of $\mathrm{Al}^{\mathrm{IV}}$ in the biotite structure (Albuquerque 1973). Low Ti contents in biotite correspond to low fO (Buddington \& Lindsley 1964). Accordingly, the low Ti and high $\mathrm{Al}^{\mathrm{IV}}$ in the biotites of the studied granitoids, suggest crystallization under relatively low temperatures and low $\mathrm{fO}_{2}$. These evidences agree with the petrographic observation that biotite is a later crystallized phase. 
Within the CTD, biotites with $\mathrm{FeO}>22$ wt. $\%$ and $\mathrm{Fe} /(\mathrm{Fe}+\mathrm{Mg})>$ 0.61 are not recorded in granitoids older than $570 \mathrm{Ma}$ (Fig 3A). On the other hand, higher $\mathrm{FeO}$ values (> 30\%) have been reported in biotites from younger granitoids (ca 520Ma) (Melo 1997).

Biotites from the studied granitoids plot into the field of biotites from sub-alkaline granites (Fig. 3B) in the $\mathrm{Al}^{\mathrm{t}}$ versus $\mathrm{Mg}$ diagram (Nachit et al. 1985) or mildly alkaline (Ferré et al. 1998).

Amphibole The amphiboles from the studied granitoids show $\mathrm{Fe} /$ $(\mathrm{Mg}+\mathrm{Fe})$ ratios ranging from 0.93 to 0.68 , similar to that of the whole rock and low $\mathrm{Fe}^{3+} /\left(\mathrm{Fe}^{2+}+\mathrm{Fe}^{3+}\right)$ ratios $(0.14-0.20)$. $\mathrm{Fe} /(\mathrm{Fe}+\mathrm{Mg})$ ratios $>0.6$ and $\mathrm{Fe}^{3+} /\left(\mathrm{Fe}^{2+}+\mathrm{Fe}^{3+}\right)$ ratios $<0.25$ are typical of granitoids crystallized under intermediate to low- $\mathrm{fO}_{2}$ conditions (Anderson \& Smith 1995). The amphiboles from the Queimadas granitoids show the highest $\mathrm{Fe} /(\mathrm{Fe}+\mathrm{Mg})$ ratios $(0.82-0.93)$. It implies that this pluton was emplaced at low levels of $\mathrm{fO}_{2}$ below QFM. The amphiboles from the Itapetim dikes show $\mathrm{Fe} /(\mathrm{Fe}+\mathrm{Mg})$ ratios in the
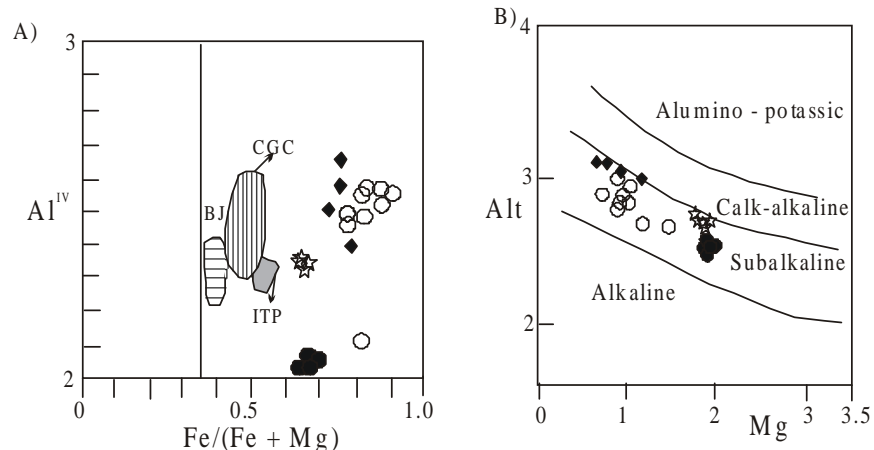

Figure 3-Biotite compositions of ca 570 Ma granitoids from the CTD, plotted in the Al versus $\mathrm{Fe} /(\mathrm{Fe}+\mathrm{Mg})$ diagram (A) and $\mathrm{Al}-\mathrm{Mg}$ diagram (B). BJ =Bom Jardim shoshonitic syenites (590 Ma); CCG - Campina Grande high-K calcalkaline granitoids $(580 \mathrm{Ma})$ and ITP = Itapetim high-K calc-alkaline granitoids (635 Ma) (Guimarães et al. 1998). Fields in B are from Nachit et al. (1985). Open circle $=$ Queimadas Pluton; closed circle $=$ Solidão Pluton diamond = serra Branca Pluton and stars = Itapetim Dykes.
0.67 - 0.68 range, suggesting that the dikes were emplaced at intermediate levels of $\mathrm{fO}_{2}$, above QFM. In the Pajeú-Paraíba Belt (PPB), amphiboles from granitoids older than 570Ma have $\mathrm{Fe} /$ $(\mathrm{Fe}+\mathrm{Mg})$ ratios $\leq 0.58$ (table 1$)$.

Fe-rich amphiboles $(\mathrm{FeO} /(\mathrm{FeO}+\mathrm{MgO})=0.82-0.84)$ have also been reported (Zanon 1997) in clinopyroxene bearing leucocratic granitoids from the Serra do Arapuá and Serra Grande Plutons (Fig. 1), which are petrographically similar to the granitoids from the Solidão Pluton. These two plutons can be fitted in the same belt of the studied granitoids. However, geochronological data are not available.

GEOCHEMISTRY The studied granitoids are sub-alkaline (Fig. 4A) and range from metaluminous to slightly peraluminous (Fig. 4B). They show similar contents of $\mathrm{SiO}(65 \%-72 \%), \mathrm{Al}_{2} \mathrm{O}_{3}(14-17 \%)$, $\mathrm{MgO}(0.2-0.6 \%)$ and $\mathrm{Rb}(100-300 \mathrm{ppm})$. The $\mathrm{K}_{2} \mathrm{O}$ contents are high $(5 \%-6.5 \%)$, except in the granodiorites from the Itapetim dikes, which show $\mathrm{K}_{2} \mathrm{O}$ contents lower than $3.2(2.8-3.2 \%)$. With the exception of the granodiorites from the Itapetim dikes which have $\mathrm{K}_{2} \mathrm{O}$ / $\mathrm{Na}_{2} \mathrm{O}$ ratios $<1$, the studied granitoids show $\mathrm{K}_{2} \mathrm{O} / \mathrm{Na}_{2} \mathrm{O}$ ratios $>1$. The granitoids from the Solidão Pluton are distinct from the others showing higher contents of $\mathrm{Na}_{2} \mathrm{O}, \mathrm{Sr}$ and $\mathrm{Ba}$ and, lower contents of $\mathrm{TiO}_{2}, \mathrm{CaO}, \mathrm{Fe}_{2} \mathrm{O}_{3} \mathrm{t}, \mathrm{Nb}$, Y, $\mathrm{Hf}$ and $\mathrm{Zr}$. The $\mathrm{FeOt} /(\mathrm{FeOt}+\mathrm{MgO})$ ratios
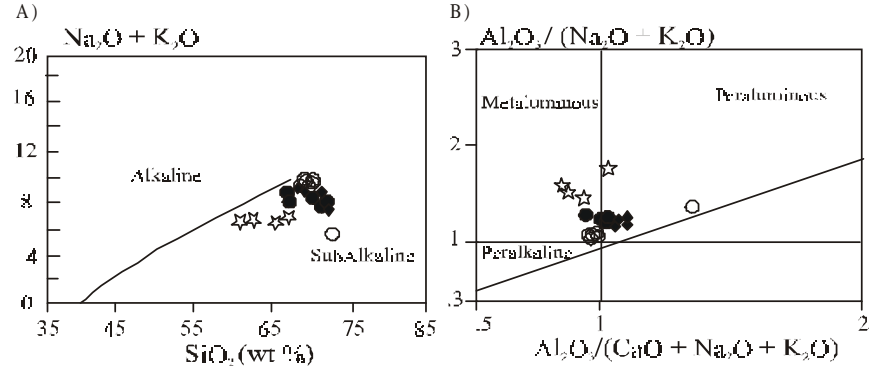

Figure 4-Geochemical plot of the ca $570 \mathrm{Ma}$ granitoids from the CTD in the $\mathrm{A} / \mathrm{NK}$ versus $\mathrm{A} / \mathrm{CNK}$, Shand diagram (A) and in the $\mathrm{Na}_{2} \mathrm{O}+\mathrm{K}_{2} \mathrm{O}$ versus $\mathrm{SiO}_{2}$ diagram (B) with fields from Irvine \& Baragar (1971). Symbols as in Fig. 3

Table 1-Composition of amphiboles from Queimadas Pluton $(Q)$; Itapetim Dykes (ID); and Solidão Pluton (CS) compared with average of amphiboles from the High-K Calc-Alkaline granitoids from Fazenda Nova Complex (FN - 588 Ma, Neves \& Vauchez 1995), Campina Grande Complex (CCG -581 Ma, Almeida 1999); and Itapetim Complex (ITP - 635 Ma, Guimarães \& Da Silva Filho 2000) from the CTD of the Borborema Province.

\begin{tabular}{|c|c|c|c|c|c|c|c|c|c|}
\hline Sample & Q33 & Q34 & ID-32 & ID-15 & CS-144 & CS-29A & FN & $\overline{C C G}$ & ITP \\
\hline $\mathrm{SiO}_{2}$ & 40.53 & 40.34 & 41.10 & 39.98 & 43.59 & 42.62 & 46.22 & 43.68 & 42.59 \\
\hline $\mathrm{TiO}_{2}$ & 1.11 & 1.55 & 0.83 & 0.69 & 0.55 & 0.34 & 0.44 & 1.18 & 0.56 \\
\hline $\mathrm{Al}_{2} \mathbf{O}_{3}$ & 9.96 & 9.77 & 12.30 & 12.27 & 7.33 & 9.45 & 8.57 & 9.49 & 10.81 \\
\hline $\mathrm{FeO}_{\mathrm{t}}$ & 27.01 & 28.45 & 21.27 & 23.03 & 24.49 & 25.58 & 16.26 & 18.39 & 20.53 \\
\hline $\mathrm{MnO}$ & 0.56 & 0.54 & 0.24 & 0 & 0.66 & 0.57 & 0.35 & 0.36 & 0.54 \\
\hline MgO & 3.23 & 3.06 & 6.45 & 6.14 & 6.05 & 5.82 & 10.50 & 9.55 & 7.86 \\
\hline $\mathrm{CaO}$ & 11.00 & 10.51 & 11.67 & 11.59 & 11.01 & 11.09 & 11.88 & 11.61 & 11.51 \\
\hline $\mathrm{Na}_{2} \mathrm{O}$ & 1.32 & 1.03 & 1.36 & 1.40 & 1.27 & 1.38 & 1.32 & 1.30 & 1.20 \\
\hline $\mathbf{K}_{2} \mathbf{O}$ & 1.56 & 1.37 & 1.37 & 1.48 & 1.30 & 1.64 & 1.12 & 1.18 & 1.23 \\
\hline TOTAL & 96.28 & 97.60 & 96.65 & 96.76 & 96.25 & 98.49 & 97.10 & 96.74 & 96.63 \\
\hline \multicolumn{10}{|c|}{ Structural formulae based on 23 Oxygens } \\
\hline TSi & 6.52 & 6.39 & 6.39 & 6.24 & 6.92 & 6.76 & 6.70 & 6.61 & 6.57 \\
\hline TAIIV & 1.48 & 1.63 & 1.62 & 1.76 & 1.08 & 1.30 & 1.31 & 1.38 & 1.43 \\
\hline CAIVI & 0.43 & 0.32 & 0.67 & 0.49 & 0.29 & 0.48 & 0.14 & 0.31 & 0.53 \\
\hline CTi & 0.14 & 0.19 & 0.10 & 0.08 & 0.06 & 0.04 & 0.16 & 0.14 & 0.06 \\
\hline CFe3+ & 0.24 & 0.36 & 0.21 & 0.47 & 0 & 0 & 0.56 & 0.37 & 0.27 \\
\hline CMg & 0.77 & 0.73 & 1.49 & 1.43 & 1.42 & 1.34 & 1.57 & 2.15 & 1.81 \\
\hline CFe2+ & 3.39 & 3.40 & 2.54 & 2.53 & 3.22 & 3.15 & 1.37 & 1.95 & 2.30 \\
\hline BFe2+ & 0 & 0.05 & 0.02 & 0.004 & 0.04 & 0.17 & 0 & 0 & 0.05 \\
\hline BMn & 0.07 & 0.07 & 0.01 & 0.02 & 0.09 & 0.08 & 0.001 & 0.05 & 0.02 \\
\hline BCa & 1.88 & 1.80 & 1.94 & 1.94 & 1.86 & 1.76 & 1.85 & 1.85 & 1.90 \\
\hline $\mathbf{B N a}$ & 0.33 & 0.26 & 0.38 & 0.39 & 0.013 & 0 & 0.09 & 0.28 & 0.05 \\
\hline $\mathrm{ACa}$ & 0 & 0 & 0 & 0 & 0.01 & 0.14 & 0 & 0.04 & 0.31 \\
\hline $\mathbf{A N a}$ & 0.08 & 0.07 & 0.03 & 0.04 & 0.38 & 0.42 & 0.30 & 0.09 & 0.24 \\
\hline AK & 0.32 & 0.28 & 0.27 & 0.30 & 0.26 & 0.33 & 0.13 & 0.22 & 0.55 \\
\hline $\mathrm{Fe} /(\mathrm{Fe}+\mathrm{Mg})$ & 0.82 & 0.84 & 0.65 & 0.68 & 0.69 & 0.71 & 0.58 & 0.51 & 0.59 \\
\hline
\end{tabular}


range from 0.78 (Itapetim dikes) to 0.92 (Queimadas Pluton). The $\mathrm{FeOt} / \mathrm{MgO}$ ratios recorded in the studied granitoids are higher than those of I- and S-type granitoids (Eby 1990).

Chondrite-normalized whole-rock REE abundance of the studied granitoids, is shown in Fig. 5B. Two distinct REE patterns were recorded: The patterns of the granitoids from Queimadas, Serra Branca Plutons and Itapetim dikes are characterized by $(\mathrm{La} / \mathrm{Yb})_{N}$ ratios in the 15 - 35 range and significant negative Eu anomalies $\left(\mathrm{Eu}^{*}=0.3-0.7\right)$. The patterns of the granitoids from the Solidão Pluton show lack or small positive Eu anomalies and are more fractionated with $(\mathrm{La} / \mathrm{Yb})_{\mathrm{N}}$ ratios in the 50 - 67 range.

The multi-element diagrams (Fig. 5B) also display the differences recorded between the Solidão and the others studied granitoids. In general, the spiderdiagrams are characterized by troughs at $\mathrm{Nb}$ and $\mathrm{Ti}$. The granitoids from Queimadas and Serra Branca Plutons and Itapetim dikes also show troughs at $\mathrm{Sr}$, while the spidergrams of the granitoids from the Solidão Pluton show peaks at $\mathrm{Sr}$, deeper troughs at $\mathrm{Ti}$ and peaks at $\mathrm{Ba}$.

In the Nb vs Y diagram of Pearce et al. (1984) the Queimadas granitoids plot within the WPG field while the other studied granites fall in the VAG + syn-COLG field (Fig. 6A). In the Rb vs $(\mathrm{Nb}+\mathrm{Y}$ ) diagram (Fig. 6B) of Pearce (1996) they cross the boundary of WPG and syn-COLG fields and occupy the post-COLG field. In the diagrams of Whalen et al. 1987 (Fig. 6C-D) some granitoid samples plot in the A-type field (Queimadas and Itapetim dikes) and others in the field of I, S, and M-type granitoids.

All granitoids investigated were emplaced after the last main phase of deformation. There is no evidence in the region indicating subduction of oceanic lithosphere contemporaneous with the emplacement of the granitoids. Thus, the VAG and syn-COLG signature recorded in some of the studied plutons could be inherited from the source rock.

DISCUSSION AND CONCLUSION The granitoids with age $c a$ $570 \mathrm{Ma}$ within the Pajeú-Paraíba are subalkaline, show high contents of $\mathrm{Ba}, \mathrm{Rb}$, LREE, $\mathrm{Zr}$ and $\mathrm{Y}$, high $\mathrm{FeO} /(\mathrm{FeO}+\mathrm{MgO})$ and $\mathrm{K}_{2} \mathrm{O} / \mathrm{Na}_{2} \mathrm{O}$ ratios and moderated to low $\mathrm{Sr}$ and $\mathrm{Nb}$, which are common features of most alkaline granite suites. However, they have low $\mathrm{SiO}_{2}$ contents ( $<70 \%$ in average), in contrast with alkaline granites, which usually have $\mathrm{SiO}_{2}$ around 74 .

The composition of biotite in granites reflects the composition of the melt from which they crystallized and indirectly the nature of their protholith (Nachit et al. 1985). The biotites of the studied granites fall mostly in the subalkaline field of Nachit et al. (1985) which corresponds to trans-alkaline compositions, according to Ferré et al. (1998).

All the previous features suggest that the granitoids of this study are similar to those described by Ferré et al.(1998) in eastern Nigeria, corresponding to trans-alkaline, ferro-potassic plutonism. The geochemical similarities between the studied granitoids (mainly the Queimadas Pluton) with those having similar ages in Eastern Nigeria (Ferré et al. 1998) suggest that this granitoids belt has a continuation in the African continent.

The $\mathrm{fO}_{2}$ conditions estimated for these granitoids are lower than those recorded in older $\left({ }^{3} 580 \mathrm{Ma}\right)$ granitoids from the PPB. The $\mathrm{fO}_{2}$ of a magma reflects that of the source region (Carmichael 1991). Thus, the slightly higher $\mathrm{Fe} /(\mathrm{Fe}+\mathrm{Mg})$ ratios recorded in the mafic silicates from Solidão Pluton and Itapetim dikes may reflect higher $\mathrm{fO}_{2}$ in their source rocks. It reflects an apparent change in the state of oxidation, decreasing from west to east, in the source rocks of the ca. $570 \mathrm{Ma}$ granitoids of the PPB. It may suggest distinct uplift rates.
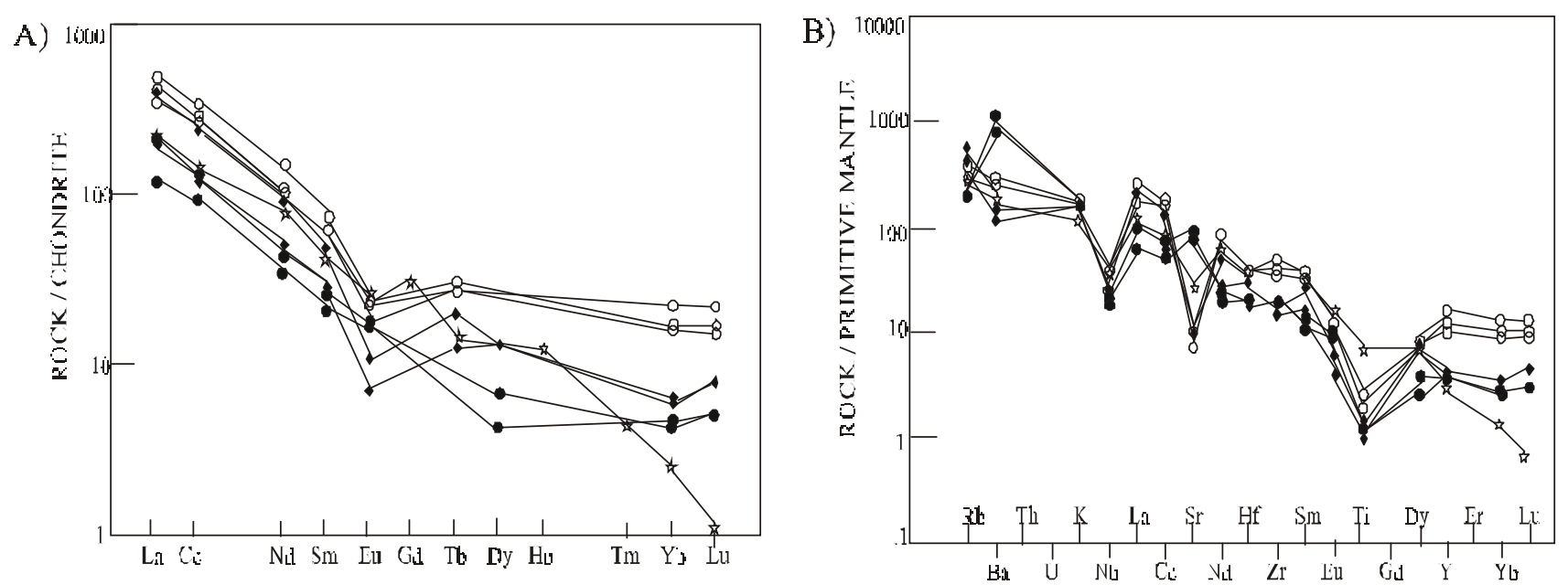

Figure 5-Chondrite (Sun 1980) normalized REE patterns (A) and multi-element diagrams of the ca 570Ma granitoids from the CTD. Symbols as in Fig. 3
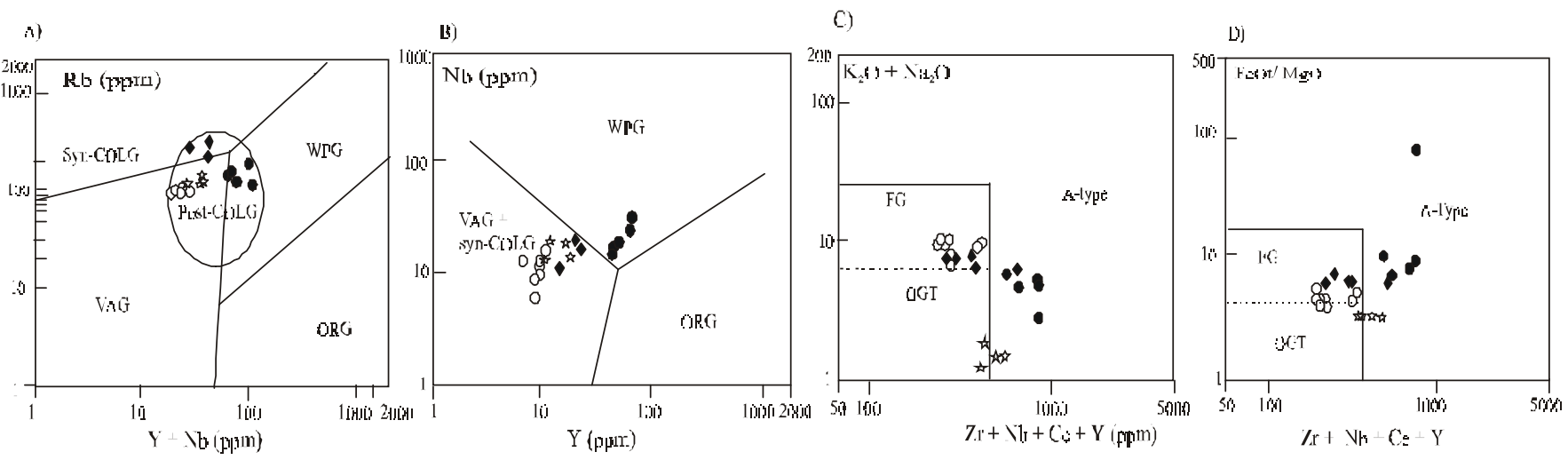

Figure 6-Trace element discrimination diagrams of the ca 570 Ma granitoids from the CTD. Fields after Pearce et al. 1984) (A); Pearce et al. 1996 (B); Whalen et al. $(1987)(C$ and D). syn-COLG = syn-collision granite; VAG = volcanic arc granite; ORG = oceanic ridge granite; post-COLG = post-collision granite; $F G=$ fractionated I-type granite; $O G T=$ unfractionated $I-S$ - and M-type granites. Symbols as in Fig. 3 
The association of field relationship, geochemical isotopic and geochronology data suggest that the studied granitoids represent a belt of granitoids, generated from distinct sources (at least isotopically), during the later stage of the Brasiliano Orogeny within the CTB of the Borborema Province.
Acknowledgements We wish to thank Drs. W.R. Van Schmus (Isotope Geochemistry Laboratories - Kansas University - USA) I.P.G. is grateful for the financial support given by CAPES - Gov. do Brasil, through the grant BEX0742/96, for a post-doctoral program at Kansas University - USA.

\section{References}

Abdel-Rahman A.M. 1994. Nature of biotites from calc-alkaline, and peraluminous magmas J. Petrol. 35:525-541.

Albuquerque C.A.1973.Geochemistry of biotites from granitic rocks, northern Portugal. Geoch. Cosmochim. Acta 37:1779-1802

Almeida C.N., Guimarães I.P., Da Silva Filho A.F. 1999. Magmatismo Brasiliano na porção leste do Terreno Pajeú-Paraíba, NE do Brasil. In: SBGq, Cong. de Geoquímica dos Países de Lingua Portuguesa, 5, and Cong. Brasileiro de Geoquímica, 6, Porto Seguro - BA, Anais: 297-299

Almeida C.N., Guimarães I.P., Da Silva Filho A.F. 1998. Magmatismo calcioalcalino intraplacas na Zona de Cizalhamento de Campina Grande, PB, NE do Brasil. In: SBG, Congresso Brasileiro de Geologia, 40,Belo Horizonte, Anais: 515

Almeida F.F., Leonardos Jr. O. H., Valença J. 1967. Granitic rocks of northeast South America. IUGS/UNESCO. $41 \mathrm{pp}$.

Anderson J.L. \& Smith D.R. 1995 The effects of temperature and $\mathrm{fO}_{2}$ on the Al-inhornblende barometer. Am. Min., 80:549-559

Araújo J.M.M. 1997. Petrologia, geoquímica e mecanismos de alojamento do Batólito granítico Solidão (PE) NE do Brasil., Universidade Federal de Pernambuco, M.Sc. Thesis, 246p.

Brito Neves B.B. 1983. O mapa geológico do Nordeste Oriental do Brasil, escala 1/ 1.000.000. Universidade de São Paulo, Livre Docência Thesis, $117 \mathrm{pp}$

Araújo J.M., Guimarães I.P., Galindo A.C. 1996. Aspectos de campo e microtexturais de fabric magmático e estado sólido do granitóide Solidão (GS) - PE. In: SBG, Congresso Brasileiro de Geologia, 40, Salvador, Anais, 6: 333-335

Buddington A.F., Lindsley D.H. 1964. Iron-titanium oxide minerals and synthetic equivalents. J. Petrol. 5:310-357.

Carmichael I.S.E. 1991 The redox states of basic and silicic magmas: A reflection of their source region. Contrib. Min. Petrol. 106:129-141

Da Silva Filho A.F., Guimarães I.P., Brito M.F.L., Pimentel M.M. 1997.Geochemical signatures of main Neoproterozoic Late-tectonic granitoids from theProterozoic Sergipano Fold Belt, Brazil: Significance for the Brasiliano Orogeny. Int. Geol. Rev. 39:639-659.

Ferré E.C., Caby R., Peucat J., Capdevila R., Monié P. 1998. Pan-African post-collision, ferro-potassic granite and quartz-monzonite plutons of Eastern Nigeria. Lithos, 45:255-279.

Guimarães I.P. \& Da Silva Filho A.F. 2000. Evidence of multiple sources involved in the genesis of the Neoproterozoic Itapetim Granitic Complex, NE Brazil, based on geochemical and isotopic data. J. South Amer. Earth Sci. in press

Guimarães I.P., Da Silva Filho A.F., Almeida C.N., Araújo J.M., Melo S.C., Sales A. 1998 The Brasiliano granitoids from the Pajeú Paraíba Belt and Texeira High: Sm-Nd isotope geochemistry and $\mathrm{U} / \mathrm{Pb}$ in zircon ages. In: $\mathrm{SBG}$, Congresso Brasileiro de Geologia, 40, Belo Horizonte, Anais: 48

Irvine T.N. \& Baragar W.R.A. 1971 A guide to the chemical classification of common volcanic rocks. Canadian J. Earth Sci. 8:523-548
Kozuch M., Bittar S.B., Van Schmus W.R., Brito Neves B.B. 1997. Late Mesoproterozoic and Middle Neoproterozoic magmatism in the Zona Transversal of Borborema Province, Brazil. In: Simpósio de Geologia do Nordeste, 18, Proceedings 15: 47-50 Liégeois J.P., Black R., Navez J., Latouch L. 1994. Early and late Pan-African orogenies in the Air assembly of terranes (Tuareg shield, Niger) Precamb. Res., 67: 59-88.

Medeiros V.C., Torres H.H., Wanderley A.A. 1997. Novos dados sobre a porção centroleste do Domínio da Zona Transversal: Mapa Geológico da folha Sumé. In: SBG-NE, Simpósio de Geologia do Nordeste, 17, Proceedings, 15: 63-68

Nachit H., Razafimahefa N., Stussi J.M., Carron J.P. 1985. Composition chimique des biotites et typologie magmatique des granitoides. Comptés Rendus Acad. Sci. Paris 301(11):813-818

Neves S.P. \& Vauchez A. 1995 Successive mixing and mingling of magmas in a plutonic complex of northeast Brazil, Lithos, 33:275-299

Pearce J., Harris N.B W. Tindle A.D. 1984. Trace element discrimination diagrams for the tectonic interpretation of granitic rocks. J. Petrol. 25:956-983

Pearce J. A. 1996 Sources and settings of granitic rocks. Episodes, 19:120-125

Santos E.J., Oliveira R.G., Paiva I.P. 1997. Terrenos no Domínio Transversal da Província da Borborema: Controles sobre acresção e retrabalhamento crustais ao sul do Lineamento Patos. In: SBG-NE Simpósio de Geologia do Nordeste, 17, Proceedings, 15:140-144

Santos E.J. 1995. O complexo granítico Lagoa das Pedras: Acreção e colisão na região de Floresta (Pernambuco) Província da Borborema. Universidade de São Paulo, Ph.D. Thesis, 220p.

Sun S.S. 1980 Chemical composition and origin of the Earth's primitive mantle. Geochim. Cosm. Acta, 46,179-192

Van Schmus W.R., Brito Neves B.B. Harckspacher P., Babinsky M. 1995. U/Pb and Sm/Nd geochronologic studies of the eastern Borborema Province, Northeastern Brazil: geochronologic studies of the eastern Borborema Provice
Initial conclusions. J. South Amer Earth Sci. 8:267-288.

Vauchez A., Neves S.P., Caby R., Corsini M., Egydio-Silva M., Arthaud M., Amaro V. 1995. The Borborema shear zone system, NE Brazil. J. South. Amer. Earth Sci. 1995. The

Whalen J.W., Currie K.L., Chappell BW. 1987. A-type granites: geochemical characteristics, discrimination and petrogenesis. Contrib. Min. Petrol. 95:407-419

Zanon C. 1997. Estudo petrológico e litogeoquímico das rochas da Serra Grande e Serra do Arapuá, Terreno Alto Pajeú - Pernambuco, Nordeste do Brasil, Universidade Federal de Pernambuco, M.Sc. Thesis, 160p

Contribution IGC-184 Received March 10, 2000 Accepted for publication May 10, 2000 